Volume 11, Issue 12, December 2020, pp. 1786-1799. Article ID: IJM_11_12_164

Available online at http://iaeme.com/Home/issue/IJM?Volume $=11 \&$ Issue $=12$

Journal Impact Factor (2020): 10.1471 (Calculated by GISI) www.jifactor.com

ISSN Print: 0976-6502 and ISSN Online: 0976-6510

DOI: 10.34218/IJM.11.12.2020.164

\title{
CAPACITY BUILDING MODEL OF GOVERNANCE PARTICIPATORY NETWORK: HOW COMMUNITY-BASED ORGANIZATION IS CHANGING THE CULTURE OF LOCAL GOVERNANCE IN INDONESIA
}

\section{Rulinawaty}

Department social of Faculty Social, Law and Humanities, Universitas Terbuka, Indonesia

\section{Sofjan Arifin}

Department social of Faculty Social, Law and Humanities, Universitas Terbuka, Indonesia

\section{Lukman Samboteng}

Department of Administrative Science, Politeknik STIA LAN Makassar, Indonesia

\section{Andriyansah}

Department Management of Faculty Economics, Universitas Terbuka, Indonesia

\begin{abstract}
The main objective of this research is to increase the capacity building of governance participatory network in the implementation of food diversification policies in Indonesia. The time series results and techniques showed that communitybased organizations (CBOs) in this study were groups of female farmers who could not carry out effective policies. The fact was that the local government as an initiator could not involve them voluntarily. They were involved because of mobilization by the local government. Therefore, governance participatory, as local capacity development and action for improving shortcomings, needs to involve CBOs as a state-community cooperation in planning, decision-making, allocating resources, and other processes. CBOs encourage governments to be more responsive, reflective, and accountable. This is a manifestation of political pressure.
\end{abstract}


Key words: Capacity building, Governance participatory network, Public policy, Policy implementation, Community-based organization

Cite this Article: Rulinawaty, Sofjan Arifin, Lukman Samboteng and Andriyansah, Capacity Building Model of Governance Participatory Network: How Communitybased Organization is Changing the Culture of Local Governance in Indonesia, International Journal of Management, 11(12), 2020, pp 1786-1799.

http://iaeme.com/Home/issue/IJM?Volume=11\&Issue=12

\section{INTRODUCTION}

It is interesting that governance participatory can make community contribute to governance. Local governments can no longer be a single player in the formulation of public policies and implementation of public policies that are approved in poverty programs, because they are related human capacity development to create social and economic change. Without such development within the people themselves, all efforts to alleviate their poverty will be difficult, even impossible(Mgawanyemba, 2008;Abegunde, 2017)The poverty program involves many stakeholders and the community. The involvement of local communities in the administration of the state can reduce conflict and increase local trust(Rahn \& Rudolph, 2005) that the policy objectives are effective and efficient in the good governance agenda. The last agenda of governance participatory is empowerment(Siegmund-Schultze, Rodorff, Köppel, \& Sobral, 2015); Noda, 2017;Speer, 2012). The capacity building of governance participatory network perspective becomes important in a public policy because it is to show a participatory approach to governance approach. In this case, it has been shown in a variety of empirical research on Goggin in 1990 that organizational capacity had a large contribution to the successful implementation of policies and/or programs. For this reason, governance participatory is a reform strategy to strengthen vertical accountability. A certain policy focuses on the interaction of marginalized communities in the local sector with local government that involves many stakeholders in the process of policy making and implementation(Wong, 2017; Junaedi, 2020; Sharhan\& Bora, 2020). This study discusses the complexity of governance participatory as an important causality in developing local capacity and correcting weaknesses by utilizing social power. The potential for governance participatory is to improve human capabilities and to empower the poor. The same study conducted by Shin, dan Lee showed the importance of governance participatory approaches in public policy research(Shin \& Lee, 2017a). Governance participatory is urgent to be implemented in developing countries. The involvement of the community in developing countries during this time is the mobilization of marginal communities to be involved in development programs.

For the food problem, Indonesia focuses on just one approach, which is self-sufficiency, for a variety of food policy outcomes. Opening new land for large-scale agriculture and importing rice are considered to be able to achieve food self-sufficiency. Farm work is the last choice for young generations in Indonesia. Being a farmer makes them at the lowest social class level. Farmers are identical with low education and poverty. The presumption of physical labor in the agricultural sector is not comparable to the income they expected. Moreover, economic policy is not on the side of the farmers. Farmer tends to be a hereditary profession of a family that they must inherit.

Then, the relevant previous research showed the study position among the other research. There are several studies that are relevant to this study, namely: Alwi and Kasmad (2018) Local collaborative network: is it smart implementer of the cocoa business development policy in Indonesia. The results showed that the farmer groups as local collaborative network were not able to carry out the policy effectively (Challiesetal., 2017). The title of the research 
is "Governance change and governance learning in Europe: stakeholder participation in environmental policy implementation". The results showed scope for policy-induced 'governance learning' wherein policy-makers drew on evidence and experience to learn how to design and execute effective participatory planning and decision-making. Shin \& Lee (2017b) Governance participatoryand trans-sectoral mobilities. The research title is "The new dynamics of adaptive preferences in the case of transport planning in Seoul, South Korea". The results showed how they developed such adaptive preferences despite expanded opportunities for participation. This research contributes to the debate on the dynamics of participatory governance. Thompsonetal (2018) with a research titled"An Exploration of the Concept of Community and Its Impact on Governance participatoryPolicy and Service Delivery in Poor Areas of Cape Town, South Africa". The results showed the construction of political and socio-economic identities and how citizens construct notions of community on the one hand and government policies on the other. Alwi\&Kasmad (2014)the research title is "Bureaucratic System Vs. People Empowerment Policy: Empirical Evidence from Cocoa Farmer Empowerment Policy in South Sulawesi Province, Indonesia". The results showed that integrated models of empowerment policy allowed the bureaucracy to empower them as people who were vulnerable to poperty.

Regarding the above research, it is necessary to create an effective and efficient capacity development model. The model is Capacity Building of Governance Participatory Network. This model combines organizational capacity theory by Goggin et.al(1990) and the concept of governance participatory. This model can increase the success of public policy implementation and the effectiveness and efficiency of the utilization of resources in synergy between the government and citizens. This concept can increase the participation of marginalized people and there will be no longer mobilization of marginalized communities both in the process of policy formulation and policy implementation (Mathur, 2008). Whereas in public policy studies, the concept of participatory capacity building can improve the performance of public policy because it is able to eliminate wicked problems and be able to meet public needs carefully( Alwi, 2015).

Agriculture is a sector that is great source of employment. Agriculture absorbs almost 50 million workers or around 23 percent of Indonesia's total population. However, it contributes to a small economic growth, so the right strategy is needed so that the steps taken can be in accordance with the expected policy goals. The agricultural sector is not only dominated by men, but also women. The number of male farmers was 49,029,347 and women farmers was 32,686,231 (Epublikasi.pertanian.go.id). People who work in the agricultural sector are vulnerable to poverty. (https://www.bps.go.id). Considering that the number of women involved in the agricultural sector is quite a lot, then a women's empowerment program was agreed upon through the Women Farmer Group (WFG'S's). The Women Farmer Group is a forum that provides opportunities for women to take part in advancing the agricultural sector.

The main emphasis of this research is on marginalized communities, namely, women farmer groups (WFGs), who are also at the heart of the food diversification policy. Governance participatory recognizes that involving the community can make a valuable contribution to the government. The main objective of this research is to develop the ability of WFGs to involve the implementation of food policies in Indonesia. 


\section{THEORETICAL REVIEW}

\subsection{Concept and Theories of Capacity Building of Governance Participatory Network}

Community capacity building is a complex problem faced by developing countries. Complex problems require the participation of all stakeholders. Engagement between government and society allows problems to be resolved effectively(Challies et al., 2017). This shows that collaboration between government and society is very important in the formulation and implementation of public policies in a strategic approach to poverty reduction. Capacity building programs aimed at reducing poverty in developing countries are not only related to technical economic problems, but also political pressures as well as distribution of resources carried out by using conventional approaches and lack of accountability in funding that makes capacity building programs not effective(Eversole, 2011)(Murray, Tshabangu, \& Erlank, 2010)

Capacity building model of governance participatory network is the interaction of government and non-government in increasing the capacity, organizational resources, and social interactions that exist within particular community and can be use to solve collective problems and to improve or enhance the welfare of local communities(Ngar-Yin Mah \& Hills, 2014). This can be done through informal social participatory processes or organized efforts. Thus, a community that could develop has resources, relationships, leadership, and support. Capacity can build through individuals, organizational relations, and governance. Local communities are actors needed in this process.

The government is no longer a single player in designing and implementing public policies. Bauer (2002),Bergh (2004),Peters \& Pierre (2006) There are various actors who represent various interests, who have a role to be empowered in making policies and influencing decisions. For actors to work effectively, governance provides actors with information, tools, resources, and communication mechanisms to facilitate participation. Governance participatory emphasizes shared interests, depending on the information distribution system, so that actors can act independently without waiting for permission from a higher level. With this system, a community can continue to grow and respond quickly to changes in environmental conditions(Yang \& Holzer, 2006)

Literature study conducted by Cuthill (2003b) showed that the participation of local people during government was a manifestation of the development of human and social capital in the realization of strong local democracy. Citizen participation is the foundation of development for modern society. Another concept that is approximately equal to the meaning of capacity building governance participatory network proposed by Chambers(1998),Innes \& Booher (2003) is Governance to be effective in developing capacity for the poor people must involve actors outside the government such as involving the community, the private sector, non-governmental organizations and possibly change, the incentives which drive the behaviour of the variety of major actors. The involvement of actors outside the government is not only for capacity building of the community, but also for formulation and implementation of government policy programs by running governance participatory.

Capacity building of governance participatory is urgently responsible and efficient in running a government program that involves its citizens for sustainable social and economic development. Capacity building of governance participatory realizes accountability, supremacy of basic law and the same division of power in overcoming or, at least, reducing poverty(Fischer, 2016). It also aims at introducing information transparency that is not only a technical problem. There is a socio-political dimension, as well as a transparency process that involves all stakeholders (government, bureaucrats, non-governmental organizations, private 
parties, and intended beneficiaries). Various types of information held and supplied by various actors in the participatory process increase their chances of being involved in a real way and are committing to the results of the joint decision-making process. Capacity building of governance participatory can improve the ability of all actors involved, both in formulation and implementation of poverty alleviation policy and programs and empowerment programs for local communities or marginalized groups.(Fischer, 2006).

The capacity building model aims to improve organizational performance, while participatory governance focuses on the cooperation of state-society. The level of participation determines government modalities that show different relationships between different sectors.Newig et al (2018) Governance participatory involves not only the state, but also society. The mechanism of governance participatory is as an institutional arrangement that aims to facilitate ordinary citizen participation in the public policy process. This is believed to not only improve the results of development activities, but also contribute to good governance, which is the basis of the democratic process. A decentralized government that applies participation has advantages in efficiency, sustainability, and equality. Capacity building of governance participatory combines local knowledge, builds relationships based on trust and reciprocity, nod forms a mechanism for feedback. It is characterized by adaptability, waste of budget only.

\subsection{Community-based Organization as Implementer of Public Policy}

The regional autonomy law enacted by the Indonesian government is a way for Communitybased Organizations (CBOs) to be involved in the state administration. Changes in relation between central and regional governments have resulted in the delegation of government authority and responsibility to local government (Bevir, 2009). Delegation of authority forms a pattern of decentralized governance that plays a key role in government. Decentralization is a form of government administration that delegates power to local governments, so that local governments will be more accountable. Further, governance becomes closer to the communities, involves citizens in policy processes and organizing public services, and thereby increase the democratic order. The emergence of CBOs is a manifestation of the trend of democratic countries. CBOs are entities that originate from the grassroots and are well-positioned to integrate local knowledge, preferences and resources into development planning and implementation, becoming a means to empower citizens. CBOs are different than formal state institutions.

Community-based organizations (CBOs) is non-profit or private organizations that represent community or significant segments of the community and work to meet community needs. $\mathrm{CBO}$ is one embodiment that guides the relationship between state actors and non-state actors in development efforts (Dill, 2010)Community-based organizations play an important and relevant role in providing services at the local level. CBOs are usually formed by and for individuals in areas that are geographically restricted and administratively determined, usually in sub-cities. The most popular participation in development efforts is currently CBOs, both for local, national, and transnational development actorsKyessi (2005), Chan (2013) CBOs open new spaces for people's participation, providing a place for people to make demands on the state in an organized way to achieve collective goals. Implementation of participatory government program and policy is necessary because it has an impact and influence on people's lives. Participatory systems enable the involvement of CBOs in planning, decision making, allocation of resource use, and other processes.

Various public policy literatures illustrate co-governance participation. Citizen participation and governance in policy programs have long used in developed countries as a policy strategy. They understand that communities and governments are more effective if they 
work together in providing services and public goods(Eversole, 2011). CBOs have democratic values and legitimize people's desire to have a role in decisions that affect their lives. CBOs also force the government to be more responsive, reflective, and accountable. This is a manifestation of political pressure. The involvement of CBOs as implementers of social policy programs in several countries has regulated in regulations or laws. Involving CBOs in the governance process has the potential to create significant policy efficiencies, such as reducing transaction costs, avoiding mistakes, and producing a qualitatively better source of ideas and policy processes. This strategy keeps the government in control as the leading sector(Adams \& Hess, 2001).

So far in developing countries, participatory governance that is carried out still revolves around the role of citizens to vote to determine who will rule. Community participation has not become a lifestyle or culture of citizens. Governance participatory is a hallmark of the implementation of modern government, viewing society as creative people who are involved in public life and state administration(Wilson, Lavis, \& Guta, 2012). The involvement of CBOs as implementers of public policy plays at least as important a role as the government and characterizes democratic countries. CBOs as implementers of public policy can realize policy objectives. CBOs ensure that the resources used in government policy programs can be used in the development process.

\section{METHODS}

The research design used was qualitative research. The use of this design was to reveal and explain the role of participatory government in implementing policies for empowering women farmers in food diversification based on the context. Research strategy used was case studies. To understand the policy implementation, we would require a lot of information from the informants as follows: (a) Local government; (b) Plantation Agency; (c) Facilitators Team; (d) Government Village head, (e) Busines men; (f) Women farmers and Women Farmer Group.

Data collection techniques covered observations, interviews, and documentations. Observations focused on the tangible objects, such as food diversification, women farmer, and their economic activities. Then, in-depth interviews were addressed to all informants mentioned above. Furthermore, various documents, such as regulations, laws, institutional activities reports relating to the implementation of the policy, were collected. The analysis techniques involved pairing patterns and time series analysis. In the study, these techniques were used together to complete with one another(Yin et al., 1989).

\section{RESULTS AND DISCUSSION}

\subsection{Implementation of Food Diversification Policies in Indonesia}

Food diversification is a program that encourages people to vary the staple food they consume so that it is not focused on one type. In Indonesia, food diversification is intended to vary the consumption of the Indonesian people so as not tofocusonrice. Indonesia has a variety of agricultural products that actually can be used as staplefoods,such as breadfruit, sweetpotatoes, taro, etc. That can be the main supporting factors for food diversification. Food diversification also plays a role in fulfilling community nutrition so that the nutrients received by the body are varied and balanced. The policy that is set by the Regulation of Minister of Agriculture No. 15 of 2013 concerning the program to increase food diversification and resilience is an integrated policy that integrates various policy instruments so as to create a dilemma for policy actors at the national level. Food diversification policies have not been effectively implemented. 
Food consumption in Indonesia is still dominated by rice. Consumption of animal products, vegetable, and fruit is still very low, while it is known that Indonesia is a country that has abundant fruits and vegetables. The average pattern of consumption of Indonesian urban residents tends to follow a westerenized style, which consumes wheat and flour, while consumption of other food, such as the tuber group, animal products, vegetables and various fruits, is consideredstill not fulfilling the ideal composition recommended.

The program made by the government is more likely to focus on rice, such as the National Rice Production Increase Program (P2BN) aimed at increasing rice production. The agricultural development policy program is generally aimed at increasing rice production, whereas Indonesia has other food ingredients such as beans and tubers. Because the failure of food diversification programs has an impact on Indonesia's generation, the prevalence of short-lived children in Indonesia tends to be static.

In general, efforts to diversify food are very important to be carried out en masse, given the trend of increasing demand for rice along with the rapid growth of the population, the increasingly impact of climate change, and the effect of giving rice to poor families (Raskin) that encourage people who previously consume staple food other than rice to consume rice. As a result, the utilization of local food as a staple food source for the local community becomes nonoptimal. This can be see from the consumption of rice per capita that increased.

The implementation of the Food Consumption Diversification Acceleration (P2KP) is the Ministry of Agriculture's Strategic Plan that focuses on food diversification. The policy has a strategic goal, which is to mobilize local food development activities through farmer groups. The local food development program certainly requires support from various parties, such as the government, extension agents, farmer groups, and women farmer groups. Farmer groups, including women farmer groups, as a medium for teaching and learning have been formed in the countryside. They are grouped voluntarily because of the demands of the progress of the farming business. Now, the group is known as the Women Farmer Group (WFG's). (Sulsel.litbang.pertanian.go.id).

Women Farmer Group, abbreviated as "WFG", is a self-help group that grows from, by, and for the community. The number of the group members ideally ranges from 20-30 people or adjusts to the conditions and areas of group work that do not exceed the limits of village administration. The Women Farmers Group is a group of farmers' wives who help with agricultural, fisheries and forestry business activities to increase the income and welfare of their families. Thus, a group of women farmers is a group that grows on the initiative, willingness, and awareness of the community itself to participate actively in increasing, developing, and empowering natural resources and human resources they own. The Women Farmers Groups (WFGs) also contribute to economic empowerment by encouraging women to achieve economic independence. The Indonesian Women Farmers Organization is a form of seriousness of women who want to play an active role in the advancement of Indonesian agriculture.

\subsection{Gender Equality: Problems and Reflection Participation in Indonesia}

Gender equality is one of our human rights. The right to live honorably free from fear and free to make choices for life is not only for men. Women also have the same rights in their essence(Kronsell, 2005). In Eastern countries, gender equality is still an issue that cannot be solved fairly. In Indonesia, women are often considered weak and only become complementary figures. In several regions in the territory of Indonesia, the culture that is formed positions women only to work in the kitchen, do the washing, and take care of family and children. This mindset is still very strongly adopted in Indonesia, supported by the social and economic environment. In Indonesia, the population of women is almost as many as men. 
The total population consisted of 133.17 million men and 131.88 million women. Indonesia's population reached 265 million, dominated by working age population aged 15-35 years. (Bapenas).

In some countries, social, economic, cultural, and educational factors are very important in the participation of the community(Valls Martínez, Cruz Rambaud, \& Parra Oller, 2019). In Indonesia, along with the four factors that were mentioned, gender factors also become important in participatory, but at the same time limit participatory movements. The attitude of hierarchical differences in society is very prominent. Differences between nobility and ordinary people rooted in traditional culture are also factors that influence participation.

The participation of poor and unemployed women is constrained by time. Women must take care of their husbands, children, and households, or they must work for their daily survival. In addition, they are constrained by the lack of technical skills in organizing collective programs and they lack material resources. They also face gender, social and economic rejection from people who have a higher hierarchy. Participation that has been carried out has tended to use traditional systems. Participation in the formal system has even alienated them from their local communities. They are categorized and labelled. The involvement of community participation in the cultural context has increasingly sharpened ethnic differences and even divided people into two groups, namely minorities and majorities. Meanwhile, formal participation is very difficult, ineffective, convoluted, and bureaucratic. The state is still considered as a part that hinders them from getting their rights economically and socially. CBOs with traditional styles that are built in their communities are a barrier to interaction between the state and society. The ties built by the community hamper dialogue and inhibit partnerships between the state and society, which are the goals of democratic decentralization. Local community participation can work well if there are no barriers or classes in CBOs. Ordinary people can get skills, knowledge, and experience by sharing knowledge in their communities. CBOs are effective grassroot organizations to carry out social movements to influence government decisions in cities and towns.

The involvement of women to participate is not easy. Various obstacles to women's participation include: (a) Women have limited time in the participation. They must manage their time and they tend to prioritize family care. (b) Women tend to dislike politics or lack political experience. They tend to lack organizational experience, so they have no experience in leading collective activities and are unable to make public decisions. (c) Men dominate formal institutions and non-formal institutions. (d) Communities that are formed by women tend to keep a distance from the government and to not be involved in government programs that are not related to religion. (e) Women tend to lack financial resources and feel inferior to the social environment because of differences in class, ethnicity, race, and education.

When gender issues are getting stronger, countries that proclaim themselves as democratic countries change the pattern of recruitment in the involvement of women in the system of government and politics. During this time, the gender voice has not been heard. With the involvement of formal and non-formal participation, it is expected that Gender will become a consideration in public decision making.

Governance Participatory: Case Study of the Implementation of Women Farmer Empowerment Policy in Food Diversification in Bone Regency, Indonesia.

The diversification of local food in the Bone Regency has long been developed by local communities, supported by extensive land conditions. Local food commodities are corn, tubers, and vegetables. These food commodities should be a priority commodity in order to diversify food in Bone Regency. In the framework of food diversification implementation in Bone Regency, the local government focuses its activities on the use of land for food crops and the socialization of various food consumption. These activities were a form of the 
government's seriousness towards the implementation of the food diversification policy. This was stated by the Regent of Bone, A. Fashar Padjalangi, during the socialization of utilization of food crops that took place on January 30, 2019.

"The people in Bone are very lucky, [because] almost all types of food can grow in this area, but the government becomes concerned because people still buy products from other districts. In the market, the products [from other districts] still flood the traditional market in Bone. I hope that with the community-based yard utilization program, the community will no longer buy sahur, but plant it themselves. Besides for family consumption, it can be useful for the economy by increasing family income. This can be successful because the people's yards are fairly large"

Conceptually, the program seeks to increase the production of a variety of food products and the use of yards. It is expected to contribute to the lifestyle and income of the community. The result of the National Socioeconomic. By running a land use program to plant various commodities, poverty rates can be reducing and poverty life can increase by selling agricultural garden products.

\subsection{Processes of Local Participatory Action}

The implementation of the policies and programs so far is interrelated with the existence of the subject and the object of the policy. Beneficiaries sometimes are only positioned as objects of policy, so that the implementation tends to be only passive mobilization and momentum. Bone Regency government makes community groups the target of food diversification policies in order to empower local communities. Women farmer groups (WFGs) are community-formed CBOs and for the community, WFGs is an important organization in achieving the goals of food diversification policy performance. At present, all villages in Bone already have a group of women farmers.

The success of the participation process depends on the Mystical Organization, which is formulated and determined in a manner that is between the government and civil society(Mega, 2003). The mutually agreed mission is the commitment of the government and civil society to achieve this mission and at the same time, to support and implement all programs to achieve organizational goals. Empowerment and diversification of food need cooperation between the government and civil society to implement various programs. Therefore, they need to agree on the mission as the direction of the organization. The community mission can develop according to the motivations and goals of the people in the community, and is likely to conflict (Mcarthur, 1995). Missions must be able to increase understanding to create a balance between personal interests and communal interests. This creates self-confidence among members of the community.

In an organization, the achievement of the mission or mysticism of the organization is achieved by management. Participatory management is management based on agreement in utilizing resources together. Management like this further encourages the participation of members in discussing problems to make joint decisions. Managers have a relatively open and non-hierarchical style in interacting with their members so that they make mutual agreements in solving problems. Performance expectations are an important factor in an organization. Participatory performance expectations include establishment of performance standards or performance indicators and their measurements. This needs to done by the government together withthe community because this is an operational standard for an organization to achieve its objectives. All organizational members need to understand this, because the success and failure of an organization are very dependent on the performance standards that have been set. 
One important component of developing organizational capacity is participatory staffing autonomy. Participatory personnel autonomy invites civil society and government in a joint group. Participatory staffing autonomy is the ability of an organization to determine its own employees or members who will be used, developed, promoted, or dismissed. This is important because the organization should make effective use of employees within the organization

The community and WFGs will have the opportunity to be involved in local government if they use the model of Capacity Building of Governance Participatory and are handled by the local government. This model helps mediate "top-down" and "bottom-up" policy formulation meetings. This model can inform and influence policy development so that the regional government and WFGs that lack resources can be helped by the application of this model and produce effective participation. Local governments can contribute to the capacity building of citizens and/or community groups by increasing their skills, knowledge, operations, orresources, so that they can participate effectively in food diversification policies.

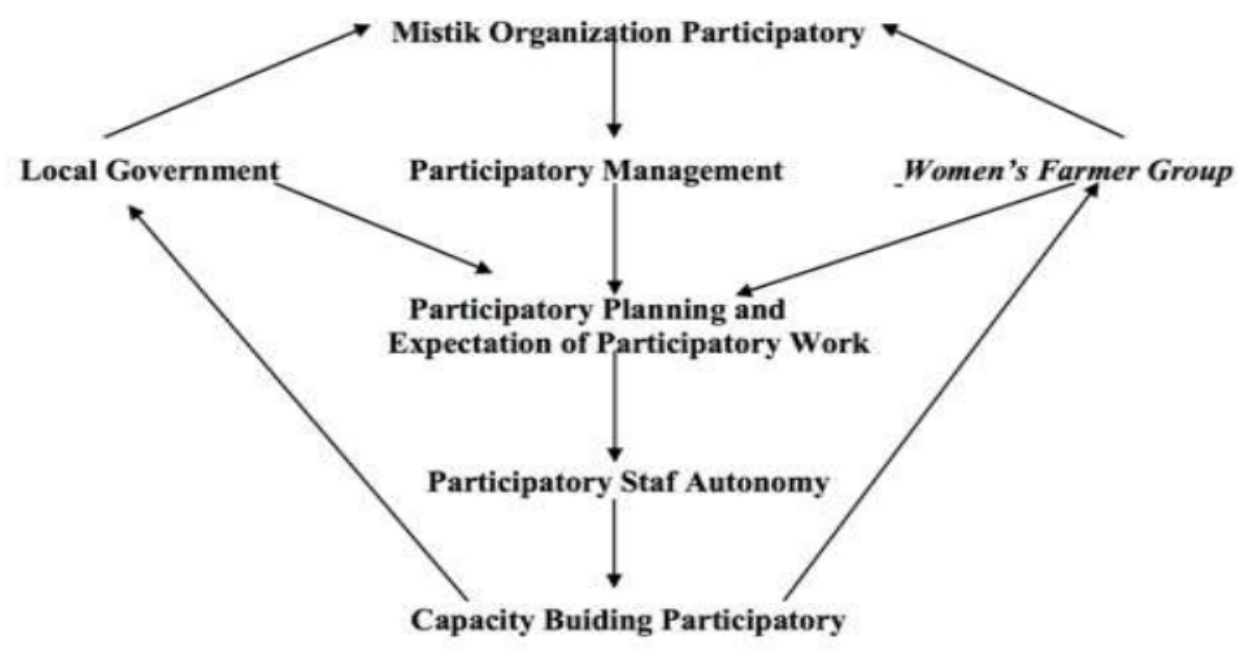

Figure 1 Model of Capacity Building of Governance Participatory

\subsection{Community-based Organization and Capacity Building: Enhancing Governance Participatory}

Increased interest in participatory public policy in the formulation and/or implementation of policies increasingly recognizes that communities can make valuable contributions to enhance governance. The focus of community participation in local scale communities, rural or urban communities has normative social interactions between groups and individuals who are potential development agents. The local community in question is disadvantaged and marginalized local communities in rural or urban areas. Thus, the local community has the potential to be in capacity building by strengthening, building, renewing, and encouraging them to help themselves out of their helplessness. Policies focusing on community-based organizations can encourage the development of their capacity. Interest in local communities helps local governments to jointly create different empowerment designs, improve different economies, and solve development problems according to the conditions of their region. The focus of community-based organization in this study was on local communities, namely, the Women Farmer Groups (WFGs) that are vulnerable to poverty. This local community is an asset to the success of the food diversification policy in Indonesia. The goal, besides the success of the food diversification policy, is also the ability to increase their capacity. 
WFGs were unable to achieve remarkable achievements in participatory food diversification policies. The recruitment of members of WFGs is based on the similarity of the commodities planted and job, which of course will create class differences in a community and create group or personal conflicts of interest. It is no longer based on jointly-built missions. Local governments also have a stake in this matter, where the requirements for community formation are very formal and rigid. WFGs can be formed if it has a certain number of members, not more or less in one work area (village). WFGs formed must be based on written permission from the local government.

CBOs should be a forum for capacity building. This community must open membership for anyone in the work area. CBOs are related to improving infrastructure, providing basic services, and/or producing other collective goods to provide benefits to the citizens of the communities in which they operate, as well as giving benefits to their members. Women farmer groups should guide the relationship between state actors and policy target groups to achieve the goal of local food diversification, WFGs in Bone Regency are unable to mobilize the community to participate. Cultural norms and religious motivations limit participation. WFGs that were formed only pursue government assistance, in which a local community should produce production of public goods that will benefit the community. CBOs need economic income from the production of goods and services. The financial resources they have will be able to develop their groups in general, and their members.

In running the B2SA program, Bone Regency government parallels the use of the yard. Before the implementation of the use of the yard, the government first conducted B2SA socialization. This was done by considering that one of the purposes of using the garden through food crops was the creation of nutritious, diverse, healthy, and safe food consumption. Government intervention in encouraging food diversification did not stop at the existence of groups and assistance. Providing counseling for planting food crops was one thing that was encouraged by the regional government. With the facilitator team, group activities as beneficiaries can be maintained to keep running.

Enchanching governance participatory can be realized by maintaining a balance between the state and society. The networking of CBOs as organizations can maintain that balance. This organization can maintain its interests against state actors and non-state actors. To improve and develop pluralism, the community must have autonomy, strength, religion, and subnational representation.

\section{CONCLUSION}

In community capacity building, local governments need to focus on building skills, knowledge, experience, leadership and managerial capabilities of citizens, community groups and public officials in the participatory governance process. The government needs to open access to the political, economic system because it is characteristic of modern sovereign societies. Participation in a form that embodies equality between citizens and local government. However, the reality in various developing countries is absurd to be realized, but still possible. The reality in various districts in Indonesia and the concept of participatory governance remain a form of citizen mobilization. Commitment to sharing power and decision-making are still merely rhetoric. Everything is still centered on the wishes of the central government and the regional government is still an extension of the central government.

The local government makes the formal system a guideline in carrying out its policy programs, while the policy goal is local communities that have local knowledge and local wisdom to do something even though it is outside the formal system. Contemporary policies try to create participation and emphasize that the participation of local people that can 
encourage innovation and change and believe that the government is more effective when the government works together. Theoretically, it highly respects what people do and how local people use resources, solve problems, and create change. However, policies fail to understand the way people work. The difference between the way people work and the way the government works makes it increasingly difficult to collaborate. The difference in understanding village development increasingly shows failed collaboration between local government and local communities. People who work in government tend to see people as powerless people, seeing them with governmental frames. The government establishes requirements for participation, such as policy directives, technical expertise, organizational frameworks, and administrative requirements that make the form of participatory governance invisible.Understanding of participatory governance makes it possible to see that CBOs and capacity building of society are at the core of contemporary public policy in participation. With this model, it will open the door for policy formulation and policy implementation to achieve broader participation.

\section{REFERENCES}

[1] Abegunde, A. A. (2017). Accomplishment Index Analysis of the Sociophysical Activities of Community-Based Organizations in a Postconflict Area of Africa. SAGE Open, 7(2), 1-25. https://doi.org/10.1177/2158244017707794

[2] Adams, D., \& Hess, M. (2001). Community in public policy: Fad or foundation? Australian Journal of Public Administration, 60(2), 13-23. https://doi.org/10.1111/1467-8500.00205

[3] Alwi, \& Kasmad, R. (2018). Local collaborative network: Is it smart implementer of the cocoa business development policy in Indonesia? International Journal of Public Policy, 14(5-6), 374-390. https://doi.org/10.1504/IJPP.2018.096640

[4] Alwi, R. K. (2014). Bureaucratic system VS People empowerment policy: emperical evidence cocoa farmer empowerment policy in south sulawesi province, Indonesia. Humanities And Social Sciences, 3(Humanit. Soc. Sci.), 313-326.

[5] Alwi, R. K. (2015). Dilemma of Values in Public Policy Accountability : Implementation of the Street Vendors Empowerment Policy Networking in Makassar City. The Sixth Asian Conference on Business \& Public Policy 2015, (Public Policy Accountability), 1-14.

[6] Bauer, M. (2002). The EU "partnership principle": still a sustainable governance device across multiple administrative arenas? Public Administration, 80, 769-789. https://doi.org/10.1111/1467-9299.00328

[7] Bergh, S. (2004). Democratic Decentralisation and Local Participation: A Review of Recent Research. Development in Practice, 14(6), 780-790. Retrieved from http://www.jstor.org/stable/4030023

[8] Bevir, M. (2009). Key Concepts in Governance. https://doi.org/10.4135/9781446214817

[9] Challies, E., Newig, J., Kochskämper, E., \& Jager, N. W. (2017). Governance change and governance learning in Europe: Stakeholder participation in environmental policy implementation. Policy and Society, 36(2), 288-303. https://doi.org/10.1080/14494035.2017.1320854

[10] Chambers, E. G., Foulon, M., Handfield-Jones, H., Hankin, S., \& Michaels, E. (1998). The War for Talent. The McKinsey Quarterly, 3, 44-57.

[11] Chan, C. K. C. (2013). Community-based organizations for migrant workers' rights: The emergence of labour NGOs in China. Community Development Journal, 48(1), 6-22. https://doi.org/10.1093/cdj/bss001 
Capacity Building Model of Governance Participatory Network: How Community-based Organization is Changing the Culture of Local Governance in Indonesia

[12] Dill, B. (2010). Community-Based Organizations (CBOs) and Norms of Participation in Tanzania: Working against the Grain. African Studies Review, 53(02), 23-48. https://doi.org/10.1353/arw.2010.0019

[13] Eversole, R. (2011). Community Agency and Community Engagement: Re-theorising Participation in Governance. Journal of Public Policy, 31(1), 51-71. https://doi.org/10.1017/s0143814x10000206

[14] Fischer, F. (2006). Participatory Governance as Deliberative Empowerment. (1992), 19-40.

[15] Fischer, F. (2016). Participatory Governance: From Theory to Practice. In Readings in Planning Theory: Fourth Edition. https://doi.org/10.1002/9781119084679.ch17

[16] Innes, J. E., \& Booher, D. E. (2003). Collaborative policymaking: Governance through dialogue. In Deliberative Policy Analysis: Understanding Governance in the Network Society. https://doi.org/10.1017/CBO9780511490934.003

[17] Junaedi, J. (2020). Implementation of Good Corporate Governance (GCG) in the Field of Securing Plantation Assets. Journal La Sociale, 1(3), 5-9.

[18] Kronsell, A. (2005). Gender, power and European integration theory. Journal of European Public Policy, 12(6), 1022-1040. https://doi.org/10.1080/13501760500270703

[19] Kyessi, A. G. (2005). Community-based urban water management in fringe neighbourhoods: The case of Dar es Salaam, Tanzania. Habitat International, 29(1), 1-25. https://doi.org/10.1016/S0197-3975(03)00059-6

[20] Mathur, N. (2008). Urban Revitalisation and Participatory Governance: Methodology for a Discursive Policy Analysis. Policy and Society, 25(2), 77-108. https://doi.org/10.1016/s14494035(06)70075-3

[21] Mcarthur, A. (1995). The Active Involvement Of Local Residents In Strategic Community Partnerships'. 23(1), 61-72.

[22] Mega, V. (2003). The participatory city. Most, 2(32), 1-26.

[23] Mgawanyemba, G. D. (2008). Community-based Organizations in Socio-economic Development: The Experience of Kasungu District in Malawi. (June).

[24] Murray, J., Tshabangu, B., \& Erlank, N. (2010). Enhancing participatory governance and fostering active citizenship: An overview of local and international best practices. Politikon, 37(1), 45-66. https://doi.org/10.1080/02589346.2010.492149

[25] Newig, J., Challies, E. D., Jager, N. W., Kochskaemper, E., \& Adzersen, A. (2018). The Environmental Performance of Participatory and Collaborative Governance: A Framework of Causal Mechanisms. Policy Studies Journal, 46(2), 269-297. https://doi.org/10.1111/psj.12209

[26] Ngar-Yin Mah, D., \& Hills, P. (2014). Participatory governance for energy policy-making: A case study of the UK nuclear consultation in 2007. Energy Policy, 74(C), 340-351. https://doi.org/10.1016/j.enpol.2014.08.002

[27] Noda, Y. (2017). Trust in the leadership of governors and participatory governance in Tokyo Metropolitan Government. Local Government Studies, 43(5), 776-797. https://doi.org/10.1080/03003930.2017.1333428

[28] Peters, B., \& Pierre, J. (2006). Handbook of Public Policy. https://doi.org/10.4135/9781848608054

[29] Rahn, W. M., \& Rudolph, T. J. (2005). American Association for Public Opinion Research A Tale of Political Trust in American Cities. Source: The Public Opinion Quarterly, 69(4), 530 560. Retrieved from http://www.jstor.org/stable/3521520\%5Cnhttp://about.jstor.org/terms 
[30] Shin, H. R., \& Lee, K. (2017a). Participatory governance and trans-sectoral mobilities: The new dynamics of adaptive preferences in the case of transport planning in Seoul, South Korea. Cities, 65, 87-93. https://doi.org/10.1016/j.cities.2017.01.012

[31] Shin, H. R., \& Lee, K. (2017b). Participatory governance and trans-sectoral mobilities: The new dynamics of adaptive preferences in the case of transport planning in Seoul, South Korea. Cities. https://doi.org/10.1016/j.cities.2017.01.012

[32] Sharhan, A. A., \& Bora, C. (2020). Effect of Audit Committee characteristics on Audit Quality: A Critical Literature Review. Journal of Advanced Research in Economics and Administrative Sciences, 1(1), 1-12.

[33] Siegmund-Schultze, M., Rodorff, V., Köppel, J., \& Sobral, M. do C. (2015). Paternalism or participatory governance? Efforts and obstacles in implementing the Brazilian water policy in a large watershed. Land Use Policy, 48, 120-130. https://doi.org/10.1016/j.landusepol.2015.05.024

[34] Speer, J. (2012). Participatory Governance Reform: A Good Strategy for Increasing Government Responsiveness and Improving Public Services? World Development. https://doi.org/10.1016/j.worlddev.2012.05.034

[35] Thompson, L., Tapscott, C., \& Wet, P. T. De. (2018). An Exploration of the Concept of Community and Its Impact on Participatory Governance Policy and Service Delivery in Poor Areas of Cape Town, South Africa. Politikon, 45(2), 276-290. https://doi.org/10.1080/02589346.2017.1398528

[36] Valls Martínez, M. del C., Cruz Rambaud, S., \& Parra Oller, I. M. (2019). Gender policies on board of directors and sustainable development. Corporate Social Responsibility and Environmental Management, 26(6), 1539-1553. https://doi.org/10.1002/csr.1825

[37] Wilson, M. G., Lavis, J. N., \& Guta, A. (2012). Community-based organizations in the health sector: A scoping review. 1-9.

[38] Wong, N. W. M. (2017). The road to environmental participatory governance in Taiwan: collaboration and challenges in incineration and municipal waste management. Journal of Environmental Planning and Management, 60(10), 1726-1740. https://doi.org/10.1080/09640568.2016.1251400

[39] Yang, K., \& Holzer, M. (2006). The performance-trust link: Implications for performance measurement. Public Administration Review, 66(1), 114-126. https://doi.org/10.1111/j.15406210.2006.00560.x

[40] Yin, R. K., Bateilian, P. G., Roger vaughan, Lande, S., A.Cantor, J., \& Deidra, D. D. (1989). Interorganizational Partnerships in Local Job Creation and Job Training Efforts: Six Case Studies. Final Report. 